Article

\title{
Effect of Different Reducing Agents on Aromatic Compounds, Antioxidant and Chromatic Properties of Sauvignon Blanc Wine
}

\author{
Ana-Marija Jagatić Korenika ${ }^{1, *(\mathbb{D},}$, Josipa Biloš ${ }^{1}$, Bernard Kozina ${ }^{1}$, Ivana Tomaz ${ }^{1}{ }^{(D}$, \\ Darko Preiner $^{1,2}$ (D) and Ana Jeromel ${ }^{1}$ \\ 1 Department of Viticulture and Enology, Faculty of Agriculture, University of Zagreb, Svetošimunska 25, \\ Zagreb 10000, Croatia; josipa.bilos@gmail.com (J.B.); bkozina@agr.hr (B.K.); itomaz@agr.hr (I.T.); \\ dpreiner@agr.hr (D.P.); amajdak@agr.hr (A.J.) \\ 2 Center of Excellence for Biodiversity and Molecular Plant Breeding, Svetošimunska 25, Zagreb 10000, Croatia \\ * Correspondence: amjagatic@agr.hr; Tel.: +38-5-1462-7986
}

Received: 6 July 2020; Accepted: 20 July 2020; Published: 24 July 2020 updates

\begin{abstract}
Sulfur dioxide $\left(\mathrm{SO}_{2}\right)$ is widely the most used enological additive with reductive, antiseptic and dissolving properties. According to increasing health concerns and the gradual decrease in total $\mathrm{SO}_{2}$ concentrations allowed in wine, alternative and supplementary agents for preservation are being investigated. For this reason, the current study was focused on the impact of different commercial reductive agents on white wine antioxidant activity and chemical composition. The effect of additives that combine sulfites, ascorbic acid and enological tannins were compared against standard 5\% sulfurous acid $\left(\mathrm{H}_{2} \mathrm{SO}_{3}\right)$ during the pre-fermentative treatments of Sauvignon Blanc must (Vitis vinifera L.). The basic parameters of quality, free amino-nitrogen and total polyphenoliccompounds in must were analyzed. Gas chromatography and spectrophotometric methods were used to investigate the overall volatile composition, antioxidant and chromatic parameters in wines. The obtained results undoubtedly pointed out the positive effect of sulfuric acid on the fermentation dynamics. Furthermore, application of combined reducing additives with potassium metabisulfite, L-ascorbic acid, gallotannins and ellagitannins, resulted in a higher antioxidant capacity and increased concentration of aromatic compounds and their odor activity values in Sauvignon Blanc wine.
\end{abstract}

Keywords: antioxidant activity; aromatic compounds; chromatic parameters; OAV; reducing agents; ROC; Sauvignon Blanc; sulfites; white wine

\section{Introduction}

Sulfites or sulfiting agents such as sulfur-containing salts (sodium and potassium metabisulfite or bisulfite), sulfurous acid and sulfur dioxide $\left(\mathrm{SO}_{2}\right)$ are the most utilized preservatives and seem indispensable in winemaking due to their antioxidative, antimicrobial and dissolving properties. While moderate oxidation improves the quality and sensory characteristics of red wines, $\mathrm{SO}_{2}$ is essential for the preservation of the color and aroma of white wines. Due to its positive conservation and regeneration effect on wine aroma, $\mathrm{SO}_{2}$ is the most effective additive in wine production [1]. Besides the direct oxygen scavenging and inhibition of oxidation enzymes, the main antioxidative function of $\mathrm{SO}_{2}$ is in its binding to hydrogen peroxide, which is the product of oxygen reduction. In that process, it prevents the aldehyde production and oxidation of other readily oxidizable compounds [2-4]. Moreover, $\mathrm{SO}_{2}$ also reduces quinones (brown polymers) back to their phenol form and improves polyphenolic wine composition [5]. Among its multifunctional properties, $\mathrm{SO}_{2}$ has a very important 
antimicrobial role against different unwanted microorganisms such as epiphytic yeasts, lactic acid bacteria (LAB) and, to a lesser extent, acetic acid bacteria [6].

In addition to being convenient and versatile, the excessive use of $\mathrm{SO}_{2}$ can have a detrimental effect on wine quality, including the neutralization of wine aroma, the formation of hydrogen sulfide, unwanted aromas and flavors and cloudiness after bottling [7,8]. Unfortunately, $\mathrm{SO}_{2}$ may cause a range of adverse clinical effects in sensitive individuals, from headaches, dermatitis, abdominal pain, diarrhea, asthma and bronchoconstriction [6,9]. As a commonly used preservative in low $\mathrm{pH}$ foods, such as juices and fermentable drinks, it is important to consider the cumulative effect on the consumers [10]. For these reasons, the International Organization of Vine and Wine gradually decreased the maximum permitted levels of total $\mathrm{SO}_{2}$ in wine [11]. In the European Union, the allowed limit for conventional wines is up to $150 \mathrm{~mL} / \mathrm{L}$ in red ones and $200 \mathrm{~mL} / \mathrm{L}$ in white and rosé wines [8]. A typical target for free $\mathrm{SO}_{2}$ to prevent wine oxidation is 20 to $40 \mathrm{mg} / \mathrm{L}$ [4], depending on wine style, aging conditions and expected shelf-life [12]. Contemporary trends that include a healthy lifestyle mean that consumers are looking for healthier and higher quality products. Due to increasing demands for low-sulfite or sulfite-free products, winemakers are facing one of the biggest challenges of modern winemaking, i.e., how to find healthier alternatives that could replace the positive properties of $\mathrm{SO}_{2}$ or to use it in combination with reduced doses of $\mathrm{SO}_{2}$ in order to protect the chemical and sensory properties of the wine.

In recent years, various groups of chemical, physical and natural methods have been proposed as promising tools for the replacement of $\mathrm{SO}_{2}$ and have been discussed in different reviews, mainly through antimicrobial properties [8,12-14]. Until today, only a few authors have analyzed the influence of some alternative antioxidants and their combined effect with $\mathrm{SO}_{2}$ on the white wine oxidation process, volatile composition and shelf life, mainly by addition prior to bottling [15-17]. As a strong antioxidant and reducing agent, more active with molecular oxygen, through the autooxidation, which generates dehydroascorbic acid and hydrogen peroxide $\left(\mathrm{H}_{2} \mathrm{O}_{2}\right)$, ascorbic acid is used to complement the effect of $\mathrm{SO}_{2}$ [16]. The main disadvantage is affecting color development in white wines and use of $\mathrm{SO}_{2}$ as a complementary agent, which can ensure efficient scavenging of dehydroascorbic acid, $\mathrm{H}_{2} \mathrm{O}_{2}$ and its degradation products [16,18]. However, according to [16] its impact on oxidative wine aging is controversial and debatable. In order to improve chemical and sensory characteristics of white wine, plant extracts, like tannins have been investigated $[15,17,19,20]$. Hydrolysable tannins, such as gallotannins extracted from oak galls and ellagitannins from oak or chestnut, which are not naturally present in grapes, make up the most sold commercial tannins [19]. According to [15] the pre-fermentative addition of enological tannins can effectively influence the oxidative phenomena on white must and wine.

Color is one of the most important sensory characteristics of white wine and according to [21], it plays a greater role in defining perceived odor than the chemical constitution of wine. Color intensity and hue measurements give useful information about phenolic concentration and tendency for oxidation, especially for wines treated with alternative reduction agents [8]. Wine aroma is a rather complex feature, formed by aromatic compounds from grapes as well as from compounds formed during and after alcoholic fermentation. The aromatic properties of Sauvignon Blanc wines mainly arise from varietal thiols and methoxypirazine, while the esters, terpenes and other aromatic compounds play a supporting role, enhancing the complexity of the wine [22]. The majority of aromas are developed during the process of alcohol fermentation and storage via enzymatic or non-enzymatic esterification of carboxylic acids [4].

There are some studies about the influence of alternative agents compared to sulfites on white wine properties, added in different stages of vinification $[1,15-17,23]$. One of the main concerns regarding these studies is that they were conducted on a laboratory-scale and on model wines so there are insufficient data on how commercially available antioxidative alternatives affect the color and aroma of different white wine styles on a larger scale. Despite growing interest in the use of natural/organic preparations as potential alternatives to $\mathrm{SO}_{2}$ (phenolics or natural extracts), the results so far have been discouraging [24]. Therefore, this paper reports on the effects of different commercial 
reducing agents that complement $\mathrm{SO}_{2}$ with ascorbic acid and enological tannins, added in the early stages of the processing, i.e., before the alcoholic fermentation with the main purpose of preserving white wine aromas, color and prevention of oxidation.

\section{Materials and Methods}

\subsection{Wine Production}

The grape variety used in this experiment was Sauvignon Blanc (Vitis vinifera L.), cultivated and processed at the Experiment Station of Faculty of Agriculture (growing hill Zagreb, Croatian Uplands). Experimental wines were produced by the processing of $450 \mathrm{~kg}$ of grapes. Manual grape harvesting was conducted on the 6 th September 2018. The grapes were processed by using of automatic destemmer and crusher and pressing was done by a hydraulic press. Basic must quality parameters like sugar concentration, total acidity, $\mathrm{pH}$, free $\alpha$-amino nitrogen and total phenols were determined. The must was divided into six $50 \mathrm{~L}$-stainless steel vessels (samples A, B, C, D, E, F) and different reducing agents were added to each sample (Figure 1). The reductive addition treatments were: (A) SUMPOvin (Inovet doo, Varaždin, Croatia), a 5\%-sulfurous acid used in the standard dosage $100 \mathrm{~mL} / \mathrm{hL}$; (B) SUMPOvin, 5\%-sulfurous acid, $50 \mathrm{~mL} / \mathrm{hL}$, (C) Aromax ${ }^{\circledR}$ (AEB, Brescia, Italy) combines $50 \%$ potassium metabisulfite $\left(54 \mathrm{mg} / \mathrm{L}\right.$ of $\left.\mathrm{SO}_{2}\right)$ and $50 \%$ L-ascorbic acid $(60 \mathrm{mg} / \mathrm{L}) ;(\mathrm{D})$ Aromax Super ${ }^{\circledR}$ (AEB, Brescia, Italy) 50\% potassium metabisulfite, $35 \%$ L-ascorbic acid and $15 \%$ pure gallotannins; (E) Aromax $\mathrm{Gal}^{\circledR}$ (AEB, Brescia, Italy) $50 \%$ of potassium metabisulfite, $35 \%$ of L-ascorbic acid and $15 \%$ of pure gallo- and ellagitannins; and (F) Noxitan ${ }^{\circledR}$ (AEB, Brescia, Italy) combination of potassium metabisulfite $\left(50 \mathrm{mg} / \mathrm{L} \mathrm{SO}_{2}\right.$ ) and ellagitannins. After $24 \mathrm{~h}$ of sedimentation, clear musts were separated from the sediment using closed pumping and were put into 12 glass containers of $25 \mathrm{~L}$. Six types of Sauvignon wines were elaborated-each experimental variant was reproduced in two replicates for each one $(n=2)$. The grape musts were inoculated with Saccharomyces cerevisiae Excellence TXL ${ }^{\circledR}$ yeasts $\left(20 \mathrm{~g} / \mathrm{hL}\right.$, Lamothe Abiet, Canejan, France) with activator of the yeast Oenostim ${ }^{\circledR}(30 \mathrm{~g} / \mathrm{hL}$, Lamothe Abiet, Canejan, France). Complex yeast nutrition Vitaferment ${ }^{\circledR}$ (Lamothe Abiet, Canejan, France) based on ammonium and vitamin B1 was added to help the yeast reproduction and decrease anomalies in the fermentation dynamics conducted at $15^{\circ} \mathrm{C}$. At the end of fermentation, the basic enological analyses were done, and $5 \%-\mathrm{H}_{2} \mathrm{SO}_{3}$ was added to correct the free $\mathrm{SO}_{2}$ concentration level at $25 \mathrm{mg} / \mathrm{L}$. After approximately 60 days, each treatment was bottled and the wines were analyzed after 3 months of storage at cellar temperature $\left(15-17^{\circ} \mathrm{C}\right)$.

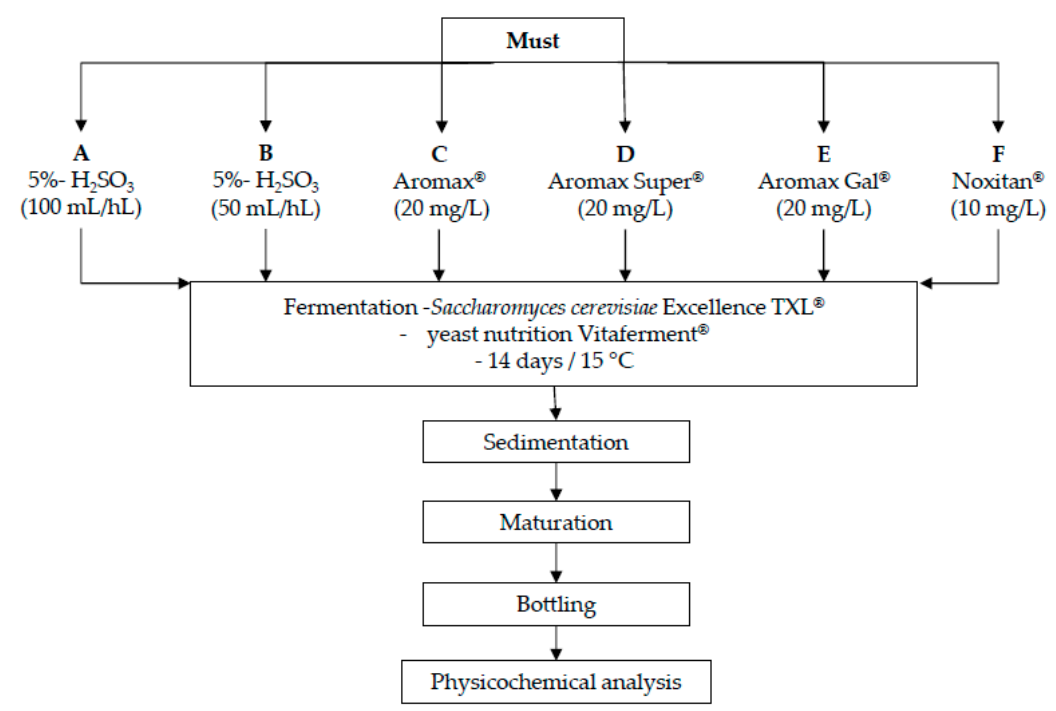

Figure 1. Scheme of the production of Sauvignon Blanc cv. white wine. 


\subsection{Must and Wine Analyses}

\subsubsection{Physicochemical Analysis}

Basic wine parameters including alcohol strength $(\% v / v)$, reducing sugar, total and volatile acids, extracts, ash, free and total $\mathrm{SO}_{2}$ and $\mathrm{pH}$ values of the given samples were analyzed using the methods prescribed by OIV [25].

\subsubsection{Free $\alpha$-Amino Nitrogen}

Free $\alpha$-amino nitrogen (FAN) was determined by spectrophotometer Specord 400, (Analytik Jena, Jena, Germany), using the method proposed by Dukes and Butzke (1998) [26].

\subsubsection{Total Phenols}

Total phenols (TP) were determined spectrophotometrically using the method by Singelton and Rossi [27] based on the color reaction of the phenolic compounds with the Folin-Ciocalteu reagent. The average of three measurements was used as the final absorbance value. The results were expressed in gallic acid equivalents ( $\mathrm{mg} / \mathrm{L}$ of gallic acid).

\subsubsection{Total Antioxidant Activity}

The total antioxidant activity (AA) of the wines was evaluated using the ABTS-free radical method described by Re et al. (1999) [28] Absorbance measurements were transformed to antioxidant activity using Trolox as a reference. Absorbance measurements were recorded on a Specord 400 spectrophotometer. The cation radical $\mathrm{ABTS}^{+}$is generated directly by the reaction of an ABTS stock solution $(7 \mathrm{mmol} / \mathrm{L})$ with $140 \mathrm{mmol} / \mathrm{L}$ potassium persulfite in a 1:0.5 stoichiometric ratio; the mixture was allowed to stand in the dark for 12 to $16 \mathrm{~h}$. Next, $5 \mathrm{~mL}$ of the formed cation radical ABTS ${ }^{+}$was mixed with $50 \mu \mathrm{L}$ aliquots of wine and the absorbance was measured at $734 \mathrm{~nm}, 6$ min after mixing. A blank control of an ethanol/water mixture was run for each assay. Results are expressed as $\mu \mathrm{mol}$ of Trolox equivalents/L of wine (TEAC/L). All determinations were carried out in triplicate.

\subsubsection{Color Parameters}

Color intensity, hue/tint/tonality and pigments were analyzed by direct measurement of wine absorbance at 420,520, and $620 \mathrm{~nm}$ by using a Specord 400 spectrophotometer (Analytik Jena, Jena, Germany). The color intensity (CI), color tint/tonality/hue (T), and the proportion of yellow (\% Ye), red (\% Rd), and blue (\% Bl) pigments were calculated as follows: $\mathrm{CI}=\mathrm{Abs} 420+\mathrm{Abs} 520+\mathrm{Abs} 620$; $\mathrm{T}=$ Abs 420/Abs 520; \% Ye $=($ Abs 420/CI $) \times 100, \% \mathrm{Rd}=($ Abs 520/CI $) \times 100, \% \mathrm{Bl}=($ Abs 620/CI $) \times$ 100 [29].

\subsubsection{Volatile Compounds Analysis}

Analysis of wine volatile compounds was performed according to the method described by [30]. In brief, isolation of volatile compounds was done by applying solid phase extraction procedure on LiChrolut EN cartridges ( $200 \mathrm{mg} / 3 \mathrm{~mL}$, Merck, Darmstadt, Germany). The GC analysis was performed on an Agilent 6890 system coupled with $5973 \mathrm{~N}$ mass spectrometer with a ZebronTM ZB-WAX capillary column $(60 \mathrm{~m} \times 0.32 \mathrm{~mm}$ i.d., with $0.5 \mu \mathrm{m}$ film thickness, Phenomenal, Torrance, USA). The flow rate of helium was $1 \mathrm{~mL} / \mathrm{min}$. The mass spectrometer was operated in an electron ionization mode at $70 \mathrm{eV}$ with selected ion monitoring (SIM) with selected ions. Compounds were first identified using NIST/EPA/NIH MS Search 2.0 and our own mass spectra libraries. Identities of most of them were then confirmed by comparison of their linear retention indices and EI mass spectra with those of reference compounds. Quantification of all examined compounds was done by the external standard method. 


\subsubsection{Odor Activity Values and Relative Odor Contributions}

Odor activity values (OAV) and relative odor contributions (ROC) are two conventional indicators used to estimate the sensory contribution of the aromatic compounds to the overall flavor of wines. $\mathrm{OAV}$ is calculated as the quotients of their concentration (c) and the corresponding odor perception threshold (t) reported in the literature [31]. Aromatic compounds with OAV $>1$ can contribute to the overall aroma of wine [32]. The ROC of each aroma compound is calculated as the ratio of the OAV of the respective compound to the total OAV of each wine [33].

\subsection{Statistical Analysis}

Mean values of concentrations and their standard deviations were calculated from three replicates. One-way analysis of variance (ANOVA) was performed using the SAS System for Windows 9.0, 2004 (SAS Institute Inc., USA). The differences in the content levels were estimated by t-test. The probability of $p \leq 0.05$ was considered statistically significant. Multivariate analysis was carried out with XLSTAT software v.2020.3.1. (Addinsoft, New York USA). The results of Principal Components Analysis (PCA) presented as two-dimensional PCA plots were used to identify the differences between wines.

\section{Results and Discussion}

\subsection{Must Composition}

After the primary processing of grapes, the concentration of sugar $\left(95^{\circ} \mathrm{Oe}\right)$, total acidity $(7.4 \mathrm{~g}$ of tartaric acid equivalents/L), free $\alpha$-amino nitrogen $(28.49(\mathrm{FAN}) / \mathrm{mg} / \mathrm{L})$, total phenols $(340.35(\mathrm{TP}) / \mathrm{mg} / \mathrm{L})$ and $\mathrm{pH}$ value $(\mathrm{pH} 3.3)$ in the sample of Sauvignon blanc must were determined. A relatively high sugar concentration determined in the must indicated a higher alcohol percentage $>13 \mathrm{vol} . \%$ in the final product. Sauvignon Blanc must contained a high amount of total acidity and the $\mathrm{pH}$ value was within the range that is optimal for white wines (from 3.1 to 3.4) [34]. The free $\alpha$-amino nitrogen (FAN) concentration of the must indicated that the grape must have needed to be supplemented with yeast nutrients, which provides the regular course of the alcoholic fermentation.

\subsection{Physicochemical Properties, Total Phenols and Antioxidant Potential of Wines}

The results of basic physicochemical analysis of wines are shown in Table 1. According to the sugar concentration of the must, concentrations of alcohol were in the range $13.5-13.7 \%, v / v$. Only the samples A and B fermented to dryness $(<4 \mathrm{~g} / \mathrm{L}$ of residual sugar), while all the other treatments resulted in semi-dry wines. Due to the fact that the same type of base wine and the same yeast were used, the difference in the fermentation dynamics can be partially prescribed to the different reducing agents used. Sugar-free extract was in the range of $17.7-18.9 \mathrm{~g} / \mathrm{L}$, while the highest value was registered in sample B. Extract is a very important component of the wine's quality, which hugely improves its fullness and harmony and the range for dry white wines is usually below $25 \mathrm{~g} / \mathrm{L}$ [35]. The total acidity (TA) was between 5.8 and $6.6 \mathrm{~g} / \mathrm{L}$. The highest concentration was measured in sample $\mathrm{B}$, while the were significantly lower in samples A and D. Volatile acid concentration was between 0.54 and $0.70 \mathrm{~g} / \mathrm{L}$, which is in accordance with the values prescribed in the Regulations of the Wine Production [36]. Considering the fact that the use of sulfites in different dosages and combinations is the main subject of this work, it is important to note that the results of the free, bound and total $\mathrm{SO}_{2}$ in wines after the fermentation showed the expected absence of the free $\mathrm{SO}_{2}$. Bound $\mathrm{SO}_{2}$ ranged from 37 to $59 \mathrm{mg} / \mathrm{L}$, while the concentration increased in the following way: $\mathrm{A}<\mathrm{B}<\mathrm{F}<\mathrm{C}<\mathrm{D}<\mathrm{E}$. The total $\mathrm{SO}_{2}$ concentration met the regulations prescribed in the Regulations of the Wine Production [36].

According to other studies, final results of TP (Table 1) were within the range of 92-482 mg/L found in white wines from Croatia [37-39]. There were significant differences in TP values among all samples, from the lowest concentration in sample A to the highest in sample E. Similar values for $\mathrm{TP}$, ranging from 191-248 mg/L, were found in other Sauvignon Blanc wines [22]. Contrary to other research $[24,40]$, a high concentration of TP was found in wines with a higher total $\mathrm{SO}_{2}$ concentration, 
which may have prevented phenolic oxidation. Results highlighted the lowest ABTS and TP values in wines with $5 \% \mathrm{H}_{2} \mathrm{SO}_{3}$ added in both doses (A and $\mathrm{B}$ ) and in wine $\mathrm{F}$ (potassium metabisulfite + ellagitannins). Significantly high antioxidant activity was detected in wines with a high concentration of bioactive phenolic compounds that were treated with reducing agents containing ascorbic acid and tannins (C, D and E).

Table 1. Physicochemical properties, total phenols and antioxidant capacity of Sauvignon Blanc wines.

\begin{tabular}{|c|c|c|c|c|c|c|}
\hline Parameter & A & B & C & D & E & $\mathbf{F}$ \\
\hline Alcohol $(\%, v / v)$ & 13. $7 \pm 0.0$ & $13.6 \pm 0.0$ & $13.6 \pm 0.0$ & $13.5 \pm 0.0$ & $13.7 \pm 0.0$ & $13.6 \pm 0.0$ \\
\hline Residual sugars (g/L) & $2.8 \pm 0.1^{\mathrm{e}}$ & $2.7 \pm 0.1^{\mathrm{e}}$ & $5.8 \pm 0.1^{b}$ & $6.2 \pm 0.1^{\mathrm{a}}$ & $5.3 \pm 0.1^{\mathrm{d}}$ & $5.6 \pm 0.1^{\mathrm{c}}$ \\
\hline Sugar-free extract $(\mathrm{g} / \mathrm{L})$ & $18.0 \pm 0.1^{\mathrm{d}}$ & $18.9 \pm 0.1^{\mathrm{a}}$ & $18.4 \pm 0.1^{b}$ & $17.7 \pm 0.1^{\mathrm{f}}$ & $17.9 \pm 0.1^{\mathrm{e}}$ & $18.3 \pm 0.1^{c}$ \\
\hline Total acidity* $(\mathrm{g} / \mathrm{L})$ & $5.8 \pm 0.1 \mathrm{e}$ & $6.6 \pm 0.1^{\mathrm{a}}$ & $6.0 \pm 0.1^{\mathrm{d}}$ & $5.9 \pm 0.0^{\mathrm{e}}$ & $6.2 \pm 0.1^{c}$ & $6.4 \pm 0.0^{\mathrm{b}}$ \\
\hline Volatile acidity ${ }^{* *}(\mathrm{~g} / \mathrm{L})$ & $0.60 \pm 0.0^{c}$ & $0.54 \pm 0.0^{\mathrm{d}}$ & $0.65 \pm 0.0^{b}$ & $0.70 \pm 0.0^{\mathrm{a}}$ & $0.65 \pm 0.0^{b}$ & $0.59 \pm 0.0^{c}$ \\
\hline $\mathrm{pH}$ & $3.3 \pm 0.0$ & $3.3 \pm 0.0$ & $3.3 \pm 0.0$ & $3.3 \pm 0.0$ & $3.3 \pm 0.0$ & $3.3 \pm 0.0$ \\
\hline $\mathrm{SO} 2$ bound $(\mathrm{mg} / \mathrm{L})$ & $37.0 \pm 0.5^{\mathrm{f}}$ & $40.0 \pm 0.5^{\mathrm{e}}$ & $59.0 \pm 0.5^{\mathrm{a}}$ & $55.0 \pm 0.5^{c}$ & $57.0 \pm 0.5^{b}$ & $45.0 \pm 0.5^{\mathrm{d}}$ \\
\hline $\mathrm{SO} 2$ total $(\mathrm{mg} / \mathrm{L})$ & $37.0 \pm 0.05^{f}$ & $40.0 \pm 0.0^{\mathrm{e}}$ & $59.0 \pm 0.5^{\mathrm{a}}$ & $55.0 \pm 0.5^{\mathrm{c}}$ & $57.0 \pm 0.5^{b}$ & $45.0 \pm 0.5^{\mathrm{d}}$ \\
\hline Ash $(g / L)$ & $1.71 \pm 0.0^{\mathrm{d}}$ & $1.74 \pm 0.0^{\mathrm{b}}$ & $1.73 \pm 0.0^{c}$ & $1.72 \pm 0.0^{c}$ & $1.72 \pm 0.0^{\mathrm{c}}$ & $1.78 \pm 0.0^{\mathrm{a}}$ \\
\hline Total phenols (mg/L GAE) & $241.69 \pm 0.0^{\mathrm{f}}$ & $250.75 \pm 0.0^{\mathrm{d}}$ & $275.63 \pm 0.0^{\mathrm{b}}$ & $267.8 \pm 0.0^{c}$ & $278.02 \pm 0.1^{\mathrm{a}}$ & $247.77 \pm 0.0^{\mathrm{e}}$ \\
\hline ABTS $(\mu \mathrm{M} / \mathrm{L}$ TE $)$ & $1.26 \pm 0.0^{\mathrm{d}}$ & $1.34 \pm 0.0^{\mathrm{c}, \mathrm{d}}$ & $1.44 \pm 0.0^{a}, \mathrm{~b}$ & $1.42 \pm 0.0^{\mathrm{a}, \mathrm{b}, \mathrm{c}}$ & $1.50 \pm 0.0^{\mathrm{a}}$ & $1.37 \pm 0.0^{b, c}$ \\
\hline
\end{tabular}

${ }^{*}$ tartaric acid and ${ }^{* *}$ acetic acid equivalents. ABTS $=$ antioxidant capacity $(\mu \mathrm{mol}$ of Trolox equivalents/L) by 2,20-azinobis-(3-ethylbenzothiazoline-6-sulfonic acid) radical cation $\left(\mathrm{ABTS}^{+}\right)$. Concentrations expressed as mean \pm standard deviation $(\mathrm{n}=3)$. Means with different superscript letters in the same row differ significantly $(p \leq 0.05)$.

\subsection{Chromatic Properties}

Figure 2 shows the results of color evaluation in terms of color intensity $(\mathrm{CI})$, hue value $(\mathrm{T})$ and proportion of yellow $(\% \mathrm{Ye})$, red $(\% \mathrm{Rd})$ and blue $(\% \mathrm{Bl})$ pigments. White wines transmit essentially all wavelengths of light to a high degree (around $80 \%$ ), but then absorb strongly in the short wavelength end of the spectrum. The absorbance values on $420 \mathrm{~nm}$ are conventional reference absorbance values for the evaluation of white wine color (Figure 2a). Thus, they are absorbing blue light while transmitting other wavelengths resulting in their typical yellow color [41]. Significantly higher absorbance at all wavelengths, especially at $420 \mathrm{~nm}$, was noticed in samples $C$ and $D$, together with highest color intensity. The low absorbance was in samples $\mathrm{A}$ and $\mathrm{B}$, which had lower concentrations of total $\mathrm{SO}_{2}$, total phenols and antioxidant activity. These results are in agreement with [15], who observed an increase in optical density at $420 \mathrm{~nm}$ when studying the substitution of $\mathrm{SO}_{2}$ by lysozyme. A significantly high proportion of yellow was detected in sample $\mathrm{E}$ with a high concentration of TP, antioxidant activity and total $\mathrm{SO}_{2}$. A significant decrease in hue value was observed in all samples compared to sample $\mathrm{E}(p<0.0001)$. There was no direct correlation between concentration of total $\mathrm{SO}_{2}$ and color parameters in other wine samples.

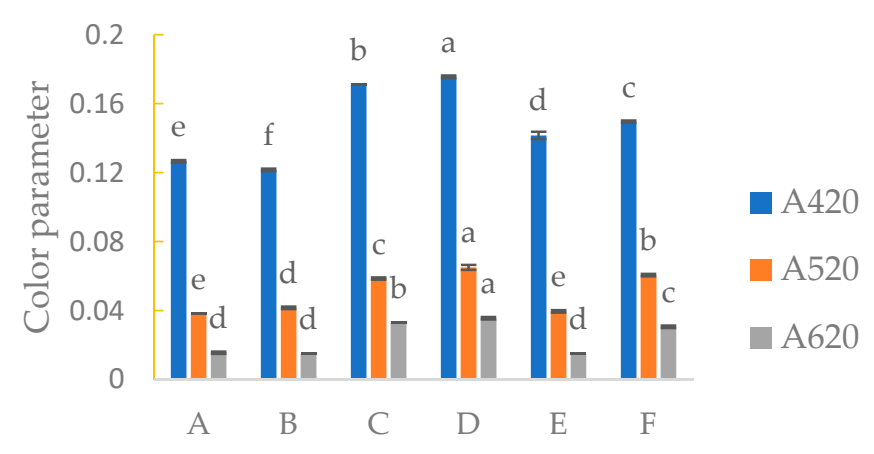

(a)

Figure 2. Cont. 


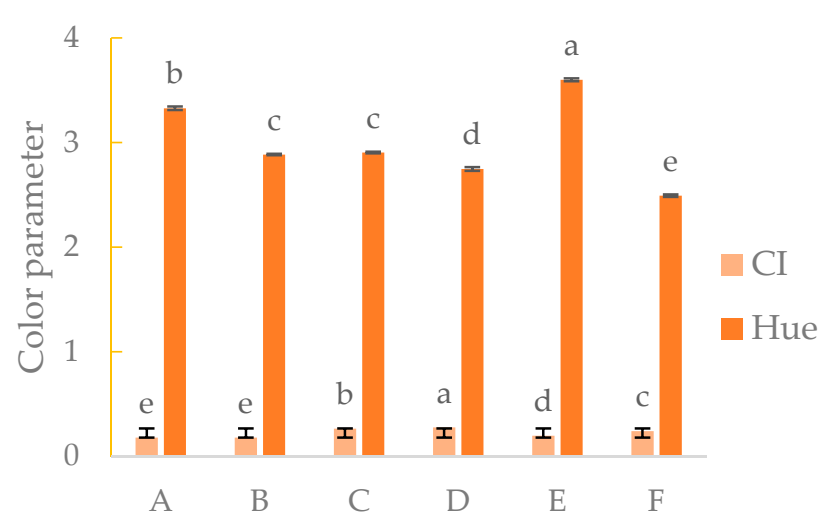

(b)

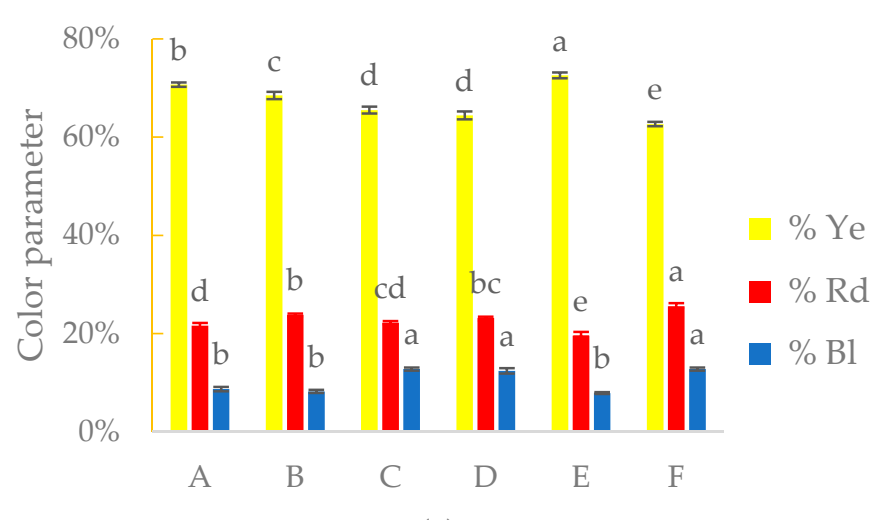

(c)

Figure 2. Absorbance at 420, 520 and $620 \mathrm{~nm}$; (a), color intensity (CI) and color hue values; (b) proportion of yellow (\% Ye), red (\% Rd) and blue (\% Bl) for Sauvignon Blanc wines; (c) columns marked with different letters $(\mathrm{a}, \mathrm{b}, \mathrm{c}, \mathrm{d}, \mathrm{e}, \mathrm{f})$ differ significantly $(p \leq 0.05)$ among treatments.

\subsection{Aroma Compounds}

Besides the basic enological properties, 92 volatile compounds divided into 7 chemical groups were analyzed (Table 2). The highest number of compounds was in the group of alcohols (24), followed by esters (21), monoterpenes (17), volatile phenols (8), aldehydes (5), fatty acids (5) and miscellaneous compounds (9). The concentration of the total aromatic compounds increased following the succession: $\mathrm{A}<\mathrm{D}<\mathrm{C}<\mathrm{F}<\mathrm{E}<\mathrm{B}$. The most represented group of the individual compounds were the alcohols with highest total concentration in samples $\mathrm{B}$ and E. According to [15], $\mathrm{SO}_{2}$ had a significant influence on alcohol production that was not completely confirmed by actual study. In this research, the total concentration of the alcohols was in the range of $99.45-127.94 \mathrm{mg} / \mathrm{L}$, which still has a positive impact on the wine aromas and enhances aromatic complexity according to [42]. The most abundant compound related to whiskey, solvent or nail polish aroma was isoamyl alcohol. The alcohols that could contribute to the wine aroma with concentrations above their sensory perception threshold were phenyl ethyl alcohol with rose notes (the highest concentration being in samples B and E), 2-methyl-1-butanol associated with black truffle (with no statistical difference among all samples) and 1-hexanol with a freshly cut grass aroma (the highest concentration in samples B and A) [43]. The highest concentration of fruity esters was found in sample $D$, while the lowest was found in sample A. The tannins seemed to have the most positive influence on ester production, which is in accordance with [15]. As suggested in other papers, these results may be due to the ability of tannins added before fermentation to affect the presence of oxygen in musts and wines, as a consequence of a double mechanism of enzyme inhibition and of radical-scavenging activity. Tannins can quickly drop the oxygen availability, contributing to preserve the ester amounts in wines [44]. The most representative 
ester in all samples was ethyl-hydrogen succinate. Esters of the succinic acid are used to imitate the smell of butter, rum, brandy, grapes and raspberries [45]. The second most representative ester was isoamyl acetate with a banana scent, then diethyl succinate with an apple aroma, ethyl octanoate with the scent of pears and ethyl decanoate with sweet fruity aroma. According to [39], the most abundant ester in white wines from Croatia, after ethyl acetate, was isoamyl acetate with a concentration between $0.31-4.14 \mathrm{mg} / \mathrm{L}$, then ethyl hexanoate and ethyl octanoate. A study on Sauvignon Blanc wines by [22] reported that ethyl acetate, isoamyl acetate and ethyl hexanoate were dominant esters.

The group of monoterpenes is representative of grape variety aroma profiles. The most common compound was nerol, with the highest concentration in samples B and D, and geraniol in sample D. The aroma of nerol can be described as flower/citrus, while the geraniol can be described as rose. This research showed different results compared to the results of the indigenous white varieties in Croatia, where the most representative monoterpene was linalool with a citrus-flowery aroma [39]. $\beta$-damascenone, a representative of C13-norisoprenoid, with its flowery aroma that improves the aroma of Sauvignon Blanc wines, was also analyzed. The concentrations were above its threshold with the highest concentration in sample F. The most abundant compound in the group of volatile phenols was tyrosol (11-23 mg/L), a natural antioxidant present in wine, as the product of the yeast metabolism. The highest concentration was in sample A. Tyrosol concentrations above $25 \mathrm{mg} / \mathrm{L}$ in still wines can cause a bitter taste [46]. The second most-represented compound was the compound with a pleasant jasmine and almond taste-benzyl alcohol, with the highest concentrations found in samples A and B. The fatty acid with the highest concentrations was propionic acid, which was quantified in sample D. All the fatty acids analyzed in this research were present in the concentrations below the sensory perception threshold that usually has a positive impact on aroma complexity. The highest concentration of the total aldehydes was in sample $\mathrm{D}$, while the most abundant compound was 2-octenal with its green-nutty aroma.

In order to evaluate the effect of applied reducing agents on the groups of the aromatic compounds in Sauvignon Blanc wines, a PCA analysis was conducted as well. The results of PCA are shown in Figure 3, where the first two components explained $70.54 \%$ of the total variance. A clear separation of the analyzed samples in a two-dimensional coordinate system was evident. Wines treated with $5 \%$ $\mathrm{H}_{2} \mathrm{SO}_{3}$ (A and $\mathrm{B}$ ) and potassium metabisulfite/ellagitannins (F) were clearly separated by PC1 from wines treated with reductive agents that include ascorbic acid (Figure 3). Pre-fermentation treatment with $\mathrm{H}_{2} \mathrm{SO}_{3}$ and potassium metabisulfite/ellagitannins was characterized with total higher alcohols and volatile phenols. Wines produced with reductive agents that include ascorbic acid were discriminated by the majority of aromatic compound groups analyzed. It was supposed that sample D, located at the rightmost of PC1, was positively correlated with total esters, aldehydes and terpenes. 
Table 2. Concentration of volatile compounds in Sauvignon Blanc wines (mg/L).

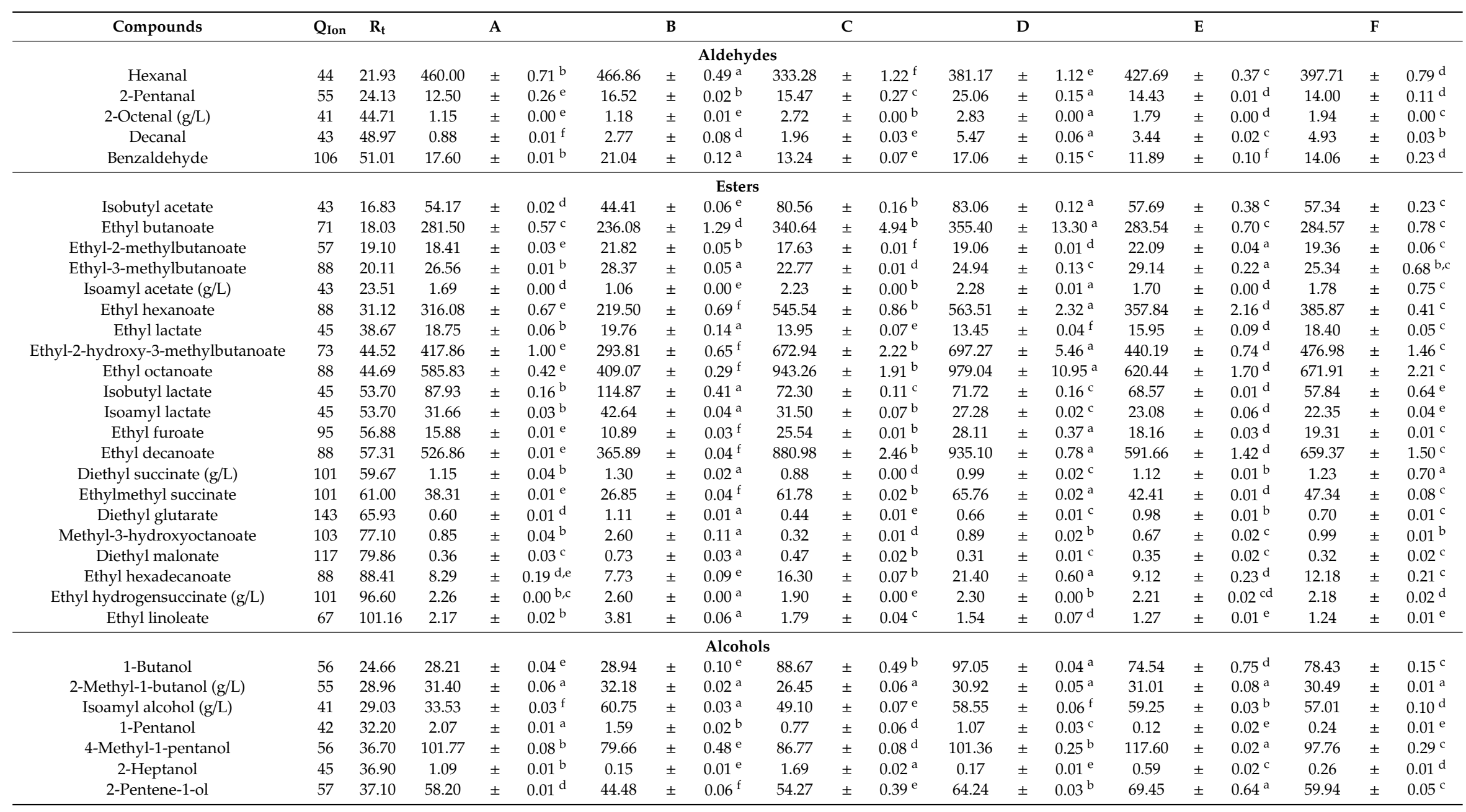


Table 2. Cont

\begin{tabular}{|c|c|c|c|c|c|c|c|c|c|c|c|c|c|c|c|c|c|c|c|c|}
\hline \multirow[t]{2}{*}{ Compounds } & \multirow[t]{2}{*}{$\mathrm{Q}_{\text {Ion }}$} & \multirow[t]{2}{*}{$\mathbf{R}_{\mathrm{t}}$} & \multicolumn{3}{|c|}{ A } & \multirow{2}{*}{\multicolumn{4}{|c|}{ B }} & \multicolumn{2}{|l|}{$\mathrm{C}$} & \multicolumn{3}{|c|}{ D } & \multicolumn{3}{|c|}{$\mathrm{E}$} & \multicolumn{3}{|c|}{$F$} \\
\hline & & & & & & & & & & & & & & & & & & & & \\
\hline 3-Methyl-1-pentanol & 56 & 37.56 & 227.87 & \pm & $0.16^{\mathrm{d}}$ & 180.03 & \pm & $0.30^{\mathrm{f}}$ & 218.65 & \pm & $0.62^{\mathrm{e}}$ & 252.42 & \pm & $0.37^{\mathrm{b}}$ & 277.34 & \pm & $0.70^{\mathrm{a}}$ & 240.88 & \pm & $0.25^{c}$ \\
\hline 1-Hexanol (g/L) & 56 & 39.88 & 1.05 & \pm & $0.01^{b}$ & 1.12 & \pm & $0.01^{\mathrm{a}}$ & 0.68 & \pm & $0.00^{\mathrm{f}}$ & 0.77 & \pm & $0.01^{\mathrm{e}}$ & 0.83 & \pm & $0.00^{\mathrm{d}}$ & 0.91 & \pm & $0.00^{c}$ \\
\hline 3-Hexene-1-ol, trans & 41 & 39.88 & 32.60 & \pm & $0.14^{\mathrm{d}}$ & 31.50 & \pm & $0.11^{\mathrm{e}}$ & 56.16 & \pm & $0.04^{\mathrm{b}}$ & 59.18 & \pm & $0.21^{\mathrm{a}}$ & 52.15 & \pm & $0.29^{\mathrm{c}}$ & 31.04 & \pm & $0.39^{\mathrm{e}}$ \\
\hline 3-Hexene-1-ol, cis & 67 & 41.76 & 16.38 & \pm & $0.04^{\mathrm{e}}$ & 12.39 & \pm & $0.12^{\mathrm{f}}$ & 26.63 & \pm & $0.28^{\mathrm{b}}$ & 28.17 & \pm & $0.21^{\mathrm{a}}$ & 19.77 & \pm & $0.07^{\mathrm{d}}$ & 21.10 & \pm & $0.06^{c}$ \\
\hline Cyclohexanol & 57 & 41.86 & 1.50 & \pm & $0.11^{\mathrm{a}}$ & 1.29 & \pm & $0.01^{b}$ & 0.92 & \pm & $0.02^{\mathrm{c}}$ & 0.80 & \pm & $0.02^{c, d}$ & 1.17 & \pm & $0.01^{\mathrm{b}}$ & 0.73 & \pm & $0.03^{\mathrm{d}}$ \\
\hline 2-Hexene-1-ol, trans & 57 & 42.72 & 9.21 & \pm & $0.25^{\mathrm{a}}$ & 8.06 & \pm & $0.03^{b}$ & 4.81 & \pm & $0.05^{\mathrm{d}}$ & 5.46 & \pm & $0.15^{\mathrm{d}}$ & 6.24 & \pm & $0.37^{c}$ & 7.55 & \pm & $0.11^{b}$ \\
\hline 1-Octen-3-ol & 57 & 45.53 & 39.36 & \pm & $0.52^{\mathrm{b}}$ & 44.70 & \pm & $0.97^{\mathrm{a}}$ & 25.01 & \pm & $1.03^{\mathrm{e}}$ & 30.37 & \pm & $0.13^{\mathrm{d}}$ & 35.43 & \pm & $0.65^{c}$ & 33.77 & \pm & $0.66^{\mathrm{c}}$ \\
\hline 1-Heptanol & 70 & 45.93 & 1.13 & \pm & $0.01 \mathrm{~d}$ & 0.82 & \pm & $0.04^{\mathrm{e}}$ & 2.49 & \pm & $0.05^{\mathrm{a}}$ & 2.59 & \pm & $0.06^{\mathrm{a}}$ & 1.60 & \pm & $0.01^{\mathrm{b}}$ & 1.39 & \pm & $0.04^{\mathrm{c}}$ \\
\hline 2-Ethyl-1-hexanol & 57 & 48.07 & 0.81 & \pm & $0.02^{\mathrm{a}}$ & 0.51 & \pm & $0.03^{c}$ & 0.64 & \pm & $0.04^{\mathrm{b}}$ & 0.84 & \pm & $0.03^{\mathrm{a}}$ & 0.66 & \pm & $0.01^{\mathrm{b}}$ & 0.39 & \pm & $0.03^{\mathrm{d}}$ \\
\hline 2,6-Dimethyl-4-heptanol & 69 & 51.86 & 5.27 & \pm & $0.04^{\mathrm{a}, \mathrm{b}}$ & 3.86 & \pm & $0.11^{\mathrm{e}}$ & 4.42 & \pm & $0.03^{\mathrm{d}}$ & 4.89 & \pm & $0.01^{\mathrm{c}}$ & 5.03 & \pm & $0.05^{b, c}$ & 5.29 & \pm & $0.03^{a}$ \\
\hline 1-Octanol & 56 & 52.32 & 5.43 & \pm & $0.01^{\mathrm{c}}$ & 5.14 & \pm & $0.01^{\mathrm{d}}$ & 5.59 & \pm & $0.04^{\mathrm{b}}$ & 5.76 & \pm & $0.04^{\mathrm{b}}$ & 5.63 & \pm & $0.05^{\mathrm{b}}$ & 6.04 & \pm & $0.04^{\mathrm{a}}$ \\
\hline 2,3-Butanediol & 45 & 53.52 & 11.09 & \pm & $0.02^{\mathrm{c}}$ & 5.58 & \pm & $0.01 \mathrm{e}$ & 7.38 & \pm & $0.05^{\mathrm{d}}$ & 5.56 & \pm & $0.01 \mathrm{e}$ & 11.86 & \pm & $0.08^{\mathrm{b}}$ & 15.91 & \pm & $0.13^{a}$ \\
\hline 2-Octen-1-ol & 57 & 56.04 & 0.11 & \pm & $0.01^{\mathrm{c}}$ & 0.23 & \pm & $0.02^{b}$ & 0.24 & \pm & $0.00^{\mathrm{b}}$ & 0.25 & \pm & $0.01^{\mathrm{b}}$ & 0.10 & \pm & $0.01^{\mathrm{c}}$ & 0.34 & \pm & $0.01^{\mathrm{a}}$ \\
\hline 1-Decanol & 55 & 64.27 & 4.44 & \pm & $0.01^{\mathrm{b}}$ & 5.07 & \pm & $0.02^{a}$ & 3.76 & \pm & $0.04^{\mathrm{e}}$ & 4.27 & \pm & $0.02^{\mathrm{c}}$ & 4.31 & \pm & $0.02^{\mathrm{c}}$ & 4.06 & \pm & $0.01 \mathrm{~d}$ \\
\hline Phenylethyl Alcohol (g/L) & 91 & 72.78 & 32.93 & \pm & $0.44^{b, c}$ & 33.42 & \pm & $0.10^{\mathrm{a}}$ & 29.82 & \pm & $0.02^{\mathrm{d}}$ & 33.39 & \pm & $0.07 \mathrm{ab}$ & 33.99 & \pm & $0.08^{\mathrm{a}}$ & 31.97 & \pm & $0.11^{\mathrm{c}}$ \\
\hline 2-Pentadecanol & 45 & 74.97 & 3.20 & \pm & $0.01^{b}$ & 2.80 & \pm & $0.13^{c}$ & 2.82 & \pm & $0.01^{\mathrm{c}}$ & 2.87 & \pm & $0.01^{\mathrm{c}}$ & 2.94 & \pm & $0.03^{\mathrm{c}}$ & 4.21 & \pm & $0.02^{\mathrm{a}}$ \\
\hline 1-Octadecanol & 83 & 104.43 & 3.55 & \pm & $0.10^{\mathrm{a}}$ & 2.60 & \pm & $0.07^{b}$ & 2.73 & \pm & $0.01^{b}$ & 2.37 & \pm & $0.13^{\mathrm{b}}$ & 2.42 & \pm & $0.04^{b}$ & 2.40 & \pm & $0.06^{\mathrm{b}}$ \\
\hline \multicolumn{21}{|c|}{ Terpenes } \\
\hline$\gamma$-Terpinene & 93 & 32.03 & 25.39 & \pm & $0.06^{\mathrm{b}}$ & 28.55 & \pm & $0.35^{\mathrm{a}}$ & 20.10 & \pm & $0.16^{\mathrm{d}}$ & 22.19 & \pm & $0.08^{\mathrm{c}}$ & 25.24 & \pm & $0.38^{\mathrm{b}}$ & 28.16 & \pm & $0.02^{\mathrm{a}}$ \\
\hline Tetrahydrolinalool & 73 & 44.32 & 53.27 & \pm & $0.09^{b}$ & 59.79 & \pm & $0.24^{\mathrm{a}}$ & 24.07 & \pm & $0.23^{\mathrm{f}}$ & 29.26 & \pm & $0.09^{\mathrm{e}}$ & 39.94 & \pm & $0.12^{\mathrm{c}}$ & 34.15 & \pm & $0.23^{d}$ \\
\hline Linalyl formate & 69 & 46.98 & 15.02 & \pm & $0.09^{b}$ & 15.70 & \pm & $0.09^{\mathrm{a}}$ & 12.21 & \pm & $0.14^{\mathrm{c}}$ & 14.95 & \pm & $0.28^{\mathrm{b}}$ & 14.70 & \pm & $0.33^{\mathrm{b}}$ & 14.99 & \pm & $0.11^{b}$ \\
\hline Linalool & 71 & 51.72 & 46.63 & \pm & $0.09^{b}$ & 52.94 & \pm & $0.76^{\mathrm{a}}$ & 35.01 & \pm & $0.40^{\mathrm{e}}$ & 39.40 & \pm & $0.07^{\mathrm{d}}$ & 42.84 & \pm & $0.03^{c}$ & 40.47 & \pm & $0.12^{\mathrm{d}}$ \\
\hline Terpinene-4-ol & 71 & 55.47 & 37.72 & \pm & $0.35^{\mathrm{b}}$ & 40.44 & \pm & $0.40^{\mathrm{a}}$ & 36.00 & \pm & $0.86^{b, c}$ & 42.16 & \pm & $0.42^{\mathrm{a}}$ & 37.18 & \pm & $0.28^{\mathrm{b}}$ & 35.04 & \pm & $0.04^{\mathrm{c}}$ \\
\hline Hotrienol & 71 & 55.74 & 51.16 & \pm & $0.72^{\mathrm{c}}$ & 55.72 & \pm & $0.21^{\mathrm{b}}$ & 51.14 & \pm & $0.02^{\mathrm{c}}$ & 58.02 & \pm & $0.16^{\mathrm{a}}$ & 51.36 & \pm & $0.24^{\mathrm{c}}$ & 48.23 & \pm & $0.30^{\mathrm{d}}$ \\
\hline$\alpha$-Terpineol & 59 & 60.92 & 4.93 & \pm & $0.01^{\mathrm{a}}$ & 4.95 & \pm & $0.03^{\mathrm{a}}$ & 4.02 & \pm & $0.06^{\mathrm{c}}$ & 4.58 & \pm & $0.06^{\mathrm{b}}$ & 4.99 & \pm & $0.05^{\mathrm{a}}$ & 4.53 & \pm & $0.05^{a}$ \\
\hline Linalool oxide pyran & 68 & 63.38 & 5.52 & \pm & $0.01^{b}$ & 4.38 & \pm & $0.06^{c}$ & 5.56 & \pm & $0.04^{a, b}$ & 5.69 & \pm & $0.01^{\mathrm{a}}$ & 4.39 & \pm & $0.01^{\mathrm{c}}$ & 5.59 & \pm & $0.02^{a, b}$ \\
\hline Citronellol & 69 & 64.53 & 10.98 & \pm & $0.06^{\mathrm{b}}$ & 19.10 & \pm & $0.11^{\mathrm{a}}$ & 8.10 & \pm & $0.04^{\mathrm{d}}$ & 11.34 & \pm & $0.08^{\mathrm{b}}$ & 10.21 & \pm & $0.13^{\mathrm{c}}$ & 10.04 & \pm & $0.11^{\mathrm{c}}$ \\
\hline Nerol & 69 & 66.54 & 159.66 & \pm & $0.74^{\mathrm{c}}$ & 171.77 & \pm & $0.69^{\mathrm{a}}$ & 150.52 & \pm & $0.23^{\mathrm{d}}$ & 174.11 & \pm & $0.78^{\mathrm{a}}$ & 164.61 & \pm & $1.48^{\mathrm{b}}$ & 157.98 & \pm & $0.03^{c}$ \\
\hline Geraniol & 69 & 68.99 & 49.29 & \pm & $0.52^{\mathrm{e}}$ & 40.18 & \pm & $0.01^{\mathrm{f}}$ & 81.83 & \pm & $0.02^{b}$ & 83.83 & \pm & $0.30^{\mathrm{a}}$ & 55.35 & \pm & $0.54^{\mathrm{d}}$ & 57.61 & \pm & $0.28^{c}$ \\
\hline Terpendiol II & 67 & 74.09 & 39.80 & \pm & $0.21^{\mathrm{b}}$ & 22.34 & \pm & $0.22^{\mathrm{d}}$ & 41.87 & \pm & $0.18^{\mathrm{a}}$ & 41.05 & \pm & $0.36^{\mathrm{a}}$ & 34.72 & \pm & $0.14^{\mathrm{c}}$ & 41.99 & \pm & $0.09^{a}$ \\
\hline 6,7-Dihydro-7-hydroxylinalool & 71 & 75.47 & 3.39 & \pm & $0.18^{\mathrm{b}}$ & 2.68 & \pm & $0.04^{\mathrm{c}}$ & 4.24 & \pm & $0.20^{\mathrm{a}}$ & 3.99 & \pm & $0.16^{\mathrm{a}}$ & 2.31 & \pm & $0.10^{\mathrm{c}}$ & 3.24 & \pm & $0.10^{b}$ \\
\hline Neralidol & 69 & 78.55 & 18.49 & \pm & $0.06^{\mathrm{a}}$ & 12.01 & \pm & $0.08^{\mathrm{d}}$ & 17.22 & \pm & $0.14^{\mathrm{c}}$ & 17.94 & \pm & $0.04^{\mathrm{b}}$ & 12.28 & \pm & $0.11^{\mathrm{d}}$ & 18.68 & \pm & $0.01^{\mathrm{a}}$ \\
\hline Geranyl acetate & 69 & 91.21 & 7.57 & \pm & $0.02^{c}$ & 7.03 & \pm & $0.06^{c}$ & 4.54 & \pm & $0.18^{\mathrm{d}}$ & 9.24 & \pm & $0.08^{\mathrm{b}}$ & 9.05 & \pm & $0.13^{\mathrm{b}}$ & 11.19 & \pm & $0.26^{a}$ \\
\hline 8-Hidroxylinalool & 43 & 91.41 & 4.51 & \pm & $0.01^{\mathrm{d}}$ & 1.81 & \pm & $0.01^{\mathrm{e}}$ & 7.50 & \pm & $0.21^{\mathrm{c}}$ & 13.22 & \pm & $0.47^{\mathrm{a}}$ & 4.62 & \pm & $0.11^{\mathrm{d}}$ & 12.02 & \pm & $0.02^{b}$ \\
\hline
\end{tabular}


Table 2. Cont.

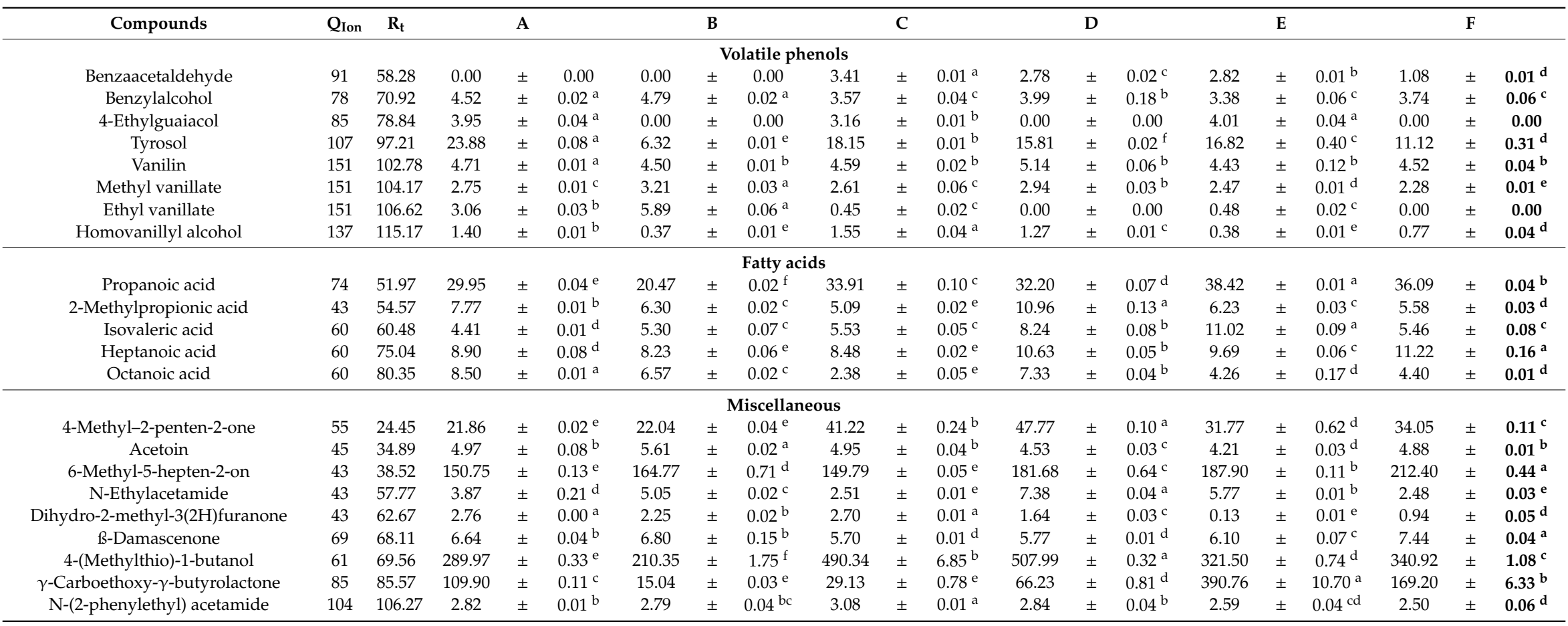

Concentrations expressed as mean \pm standard deviation $(\mathrm{n}=3)$. Means with different superscript letters in the same row differ significantly $(p \leq 0.05)$. Legend: $\mathrm{Q}_{\text {Ion }}=$ Ion quantifier;

$\mathrm{R}_{\mathrm{t}}=$ retention time. 


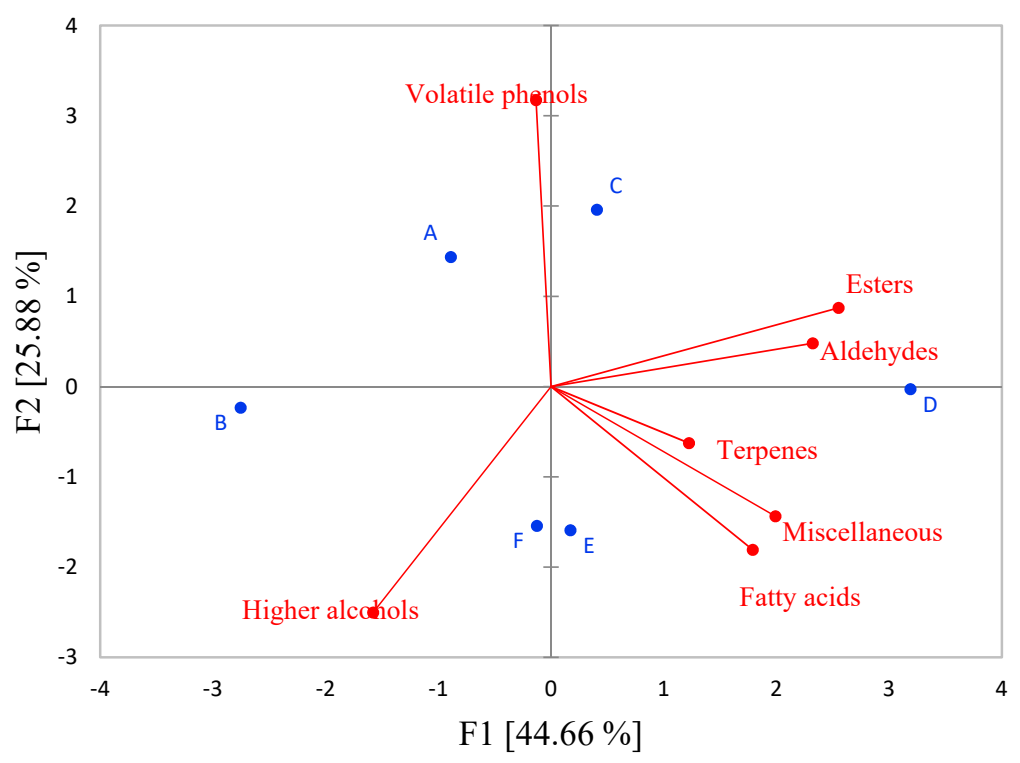

Figure 3. Distribution of the wine samples in a two-dimensional coordinate system defined by the first two principal components (PC1 and PC2) according to the applied reducing agents (A, B, C, D, E, F) and groups of aromatic compounds.

\subsection{Odor Activity Value (OAV) and Relative Odor Contribution (ROC)}

To evaluate the effects of individual aromatic compounds on overall aroma profile of Sauvignon Blanc wines, OAV values and ROC indexes were calculated. Each aromatic compound has been associated with an odor descriptor as reported in the literature (Table 3). Only 17 compounds out of 92 exceeded the threshold values $(\mathrm{OAV}>1)$. In sample $\mathrm{D}$, 2-octenal $(\mathrm{OAV}=942.40)$ had the highest $\mathrm{OAV}$ among all compounds, more than two times higher than in samples A and B. Together with hexanal $(\mathrm{OAV}=103.75$ in $\mathrm{B})$ it has an enhanced green and grass aroma, common descriptors of Sauvignon Blanc wines. $B$-damascenone had the second highest OAV (148.80) in sample F. Isoamyl acetate had the highest OAV (76.01) in sample D, again more than two times higher than in sample B. Among terpenes, only geraniol and linalool had an OAV $>1$, both with a flowery-citrus aroma, with high values in samples A and B. The higher alcohol, i.e., 1-octen-3-ol, which had the highest OAV in samples B (44.70) and A (39.36), is associated with a mushroom aroma. The highest OAV (2.42) of rose-like phenylethyl alcohol was noted in sample E. The same number of the highest OAVs was found in samples D and B, mostly from fruity esters, but the highest OAV in total was noted for sample D. On the basis of the ROC index, a further contribution of each individual compound on the wine aroma was analyzed (Table 3). Although the most abundant compounds with the highest OAVs were found in wine sample D, some of them, like 2-octenal and ethyl hexanoate, ethyl octanoate and ethyl butanoate displayed greater relative odor contribution (ROC) in samples $C$ and A. Phenylethyl alcohol and $B$-damascenone had the highest ROCs in sample $\mathrm{B}$, even though their OAVs were the highest in samples $\mathrm{E}$ and $\mathrm{F}$, respectively. 
Table 3. Odor activity values (OAV), relative odor contribution (ROC) and odor thresholds (OTH) of aromatic compounds with OAV > 1 in Sauvignon Blanc wines.

\begin{tabular}{|c|c|c|c|c|c|c|c|c|c|c|c|c|c|c|}
\hline \multirow[t]{2}{*}{ Compounds } & \multirow{2}{*}{$\begin{array}{c}\text { OTH } \\
(\mathrm{mg} / \mathrm{L})\end{array}$} & \multirow[t]{2}{*}{ Odor Descriptor } & \multicolumn{5}{|c|}{ OAV } & \multicolumn{7}{|c|}{ ROC (\%) } \\
\hline & & & A & B & $\mathrm{C}$ & D & E & F & A & B & C & D & E & F \\
\hline 2-Octenal & $0.003^{1}$ & Green, nut, fat & 384.00 & 394.64 & 905.60 & 942.40 & 597.70 & 647.29 & 46.82 & 49.72 & 69.61 & 69.13 & 60.37 & 60.87 \\
\hline Hexanal & $0.045^{1}$ & Green, grass & 102.22 & 103.75 & 74.06 & 84.70 & 95.04 & 88.38 & 12.46 & 13.07 & 5.69 & 6.21 & 9.60 & 8.31 \\
\hline Isoamyl acetate & $0.030^{2}$ & Banana & 56.42 & 35.24 & 74.45 & 76.01 & 56.76 & 59.47 & 6.88 & 4.40 & 5.72 & 5.57 & 5.73 & 5.59 \\
\hline Ethyl octanoate & $0.580^{3}$ & Sweet, floral, fruity, pear & 1.01 & $<1$ & 1.62 & 1.69 & 1.07 & 1.16 & 0.12 & - & 0.12 & 0.12 & 0.11 & 0.11 \\
\hline Ethyl decanoate & $0.200^{3}$ & Floral & 2.63 & 1.83 & 4.40 & 4.67 & 2.96 & 3.30 & 0.32 & 0.23 & 0.33 & 0.34 & 0.30 & 0.31 \\
\hline Ethyl hexanoate & $0.014^{2}$ & Fruity, green apple, banana & 22.56 & 15.68 & 38.97 & 40.25 & 25.56 & 27.56 & 2.75 & 1.98 & 2.99 & 2.95 & 2.58 & 2.59 \\
\hline Ethyl butanoate & $0.020^{4}$ & Pineapple, apple & 14.07 & 11.80 & 17.03 & 17.77 & 14.18 & 14.23 & 1.71 & 1.49 & 1.30 & 1.30 & 1.43 & 1.34 \\
\hline Isoamyl lactate & $0.0016^{5}$ & Fruit, apple, banana & 19.79 & 26.65 & 19.69 & 17.05 & 14.42 & 13.97 & 2.41 & 3.36 & 1.51 & 1.25 & 1.45 & 1.31 \\
\hline Ethyl-3-methylbutanoate & $0.003^{4}$ & Fruity, pineapple & 8.85 & 9.46 & 7.59 & 8.31 & 9.71 & 8.45 & 1.07 & 1.19 & 0.58 & 0.61 & 0.98 & 0.79 \\
\hline Ethyl-2-methylbutanoate & $0.018^{4}$ & Apple & 1.02 & 1.21 & $<1$ & 1.06 & 1.23 & 1.08 & 0.12 & 0.15 & - & 0.07 & 0.12 & 0.10 \\
\hline Ethyl hexadecanoate & $0.0015^{6}$ & Fruity, wax & 5.53 & 5.15 & 10.87 & 14.27 & 6.08 & 8.12 & 0.67 & 0.65 & 0.83 & 1.04 & 0.61 & 0.76 \\
\hline Phenylethyl alcohol & $14^{2}$ & Floral, rose, honey & 2.35 & 2.39 & 2.13 & 2.38 & 2.42 & 2.28 & 0.28 & 0.30 & 0.16 & 0.17 & 0.24 & 0.21 \\
\hline 2-Methyl-1-butanol & $30^{7}$ & Whiskey, burnt, nail polish & 1.05 & 1.07 & $<1$ & 1.03 & 1.03 & 1.02 & 0.13 & 0.13 & - & 0.07 & 0.10 & 0.09 \\
\hline 1-Octen-3-ol & $0.001^{8}$ & Mushroom & 39.36 & 44.70 & 25.01 & 30.37 & 35.43 & 33.77 & 4.80 & 5.63 & 1.92 & 2.22 & 3.58 & 3.17 \\
\hline Geraniol & $0.020^{2}$ & Citrus, citric fruit & 24.64 & 2.01 & 4.09 & 4.19 & 2.77 & 2.88 & 3.00 & 0.25 & 0.31 & 0.31 & 0.28 & 0.27 \\
\hline Linalool & $0.025^{2}$ & Citrus, floral, sweet & 1.86 & 2.12 & 1.40 & 1.58 & 1.71 & 1.62 & 0.23 & 0.27 & 0.11 & 0.11 & 0.17 & 0.15 \\
\hline B-Damascenone & $0.00005^{9}$ & Sweet, fruity, floral, honey & 132.80 & 136.00 & 114.00 & 115.40 & 122.00 & 148.80 & 16.19 & 17.13 & 8.76 & 8.46 & 12.32 & 13.99 \\
\hline
\end{tabular}

Odor threshold values (OTH) from the literature: ${ }^{1}[47],{ }^{2}[48],{ }^{3}[49],{ }^{4}[50],{ }^{5}[51],{ }^{6}[52], 7[53],{ }^{8}[54],,^{9}[55]$. 
To further define the aromatic compounds influencing the wines, OAV data were used for PCA analyses (Figure 4). Variables included in the PCA were limited to OAV $>1$ (Table 3). As it can be seen from Figure 4, the first principal component (PC1), accounting for $70.50 \%$ of the total variance, differentiates samples $C$ and D from the other four samples, while PC2 that explains $12.51 \%$ of variance separates samples A, B, C from D, E and F. In the loading plot shown, most varietal aromas like linalool, geraniol and $\mathrm{B}$-damascenone were located on the right side, positively linked with $\mathrm{PC} 1$, indicating that the addition of $\mathrm{H}_{2} \mathrm{SO}_{3}$ resulted in a higher sensory contribution of these aromatic compounds. On the other hand, PC2 contributed to the differentiation of wines D and E from the other samples. Wine $\mathrm{D}$ treated with potassium metabisulfite, ascorbic acid and gallotannins, on the negative side of PC2, was characterized with higher contributions of most ethyl esters and therefore, fruity aromas. The PCA analysis shows that the treatment of wine $\mathrm{E}$ with a combination of potassium metabisulfite/ascorbic acid/gallo- and ellagitannins, increased the sensory contribution of higher alcohols like phenylethyl alcohol with a floral aroma.

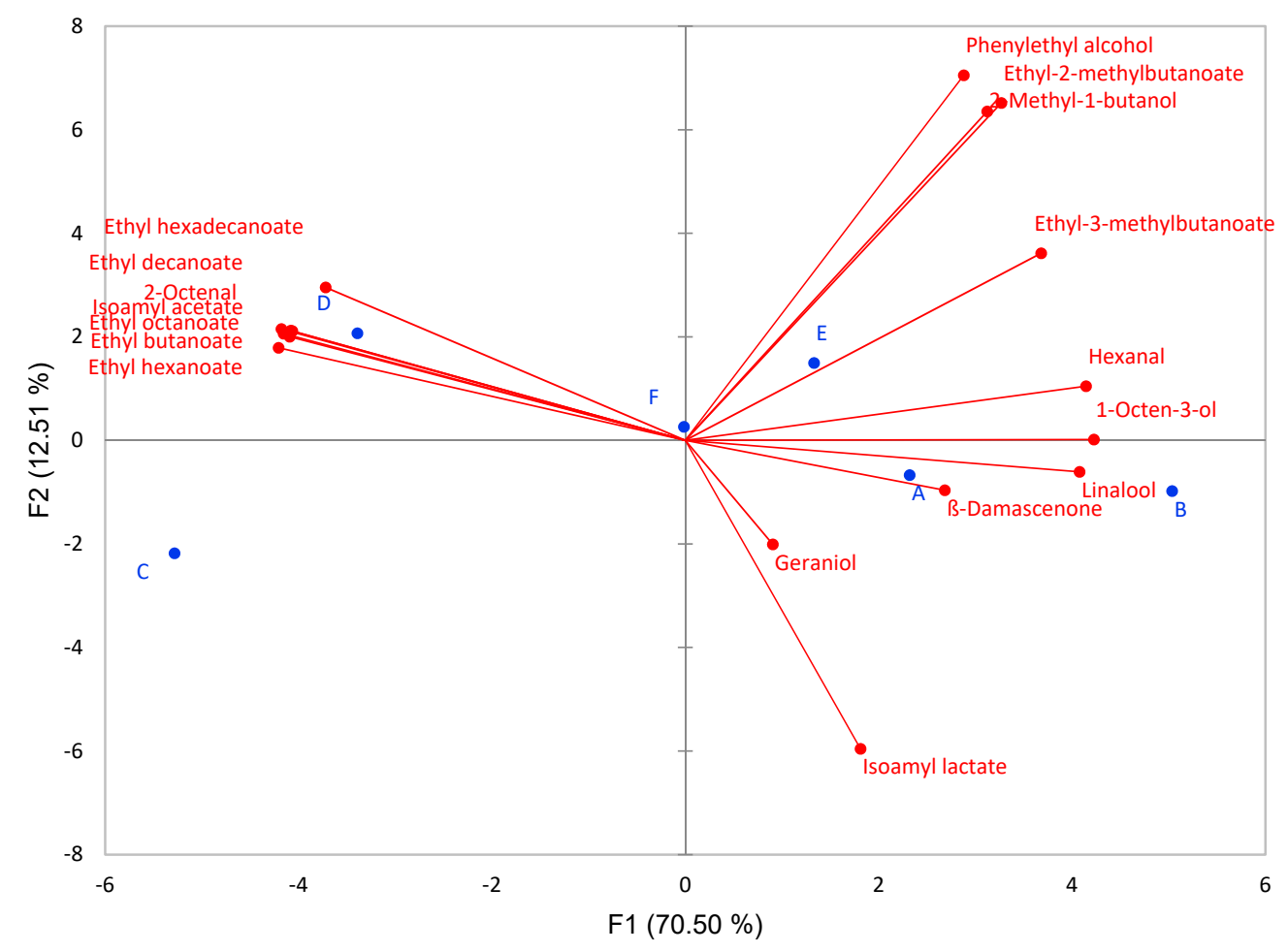

Figure 4. Distribution of the wine samples in a two-dimensional coordinate system defined by the first two principal components (PC1 and PC2) according to the applied reducing agents (A, B, C, D, E, F) and aromatic compounds with OAV $>1$ in Sauvignon Blanc wines.

\section{Conclusions}

Pre-fermentative treatments with different reducing agents had a significant effect on the physicochemical, antioxidant, aromatic and chromatic parameters of Sauvignon Blanc wines. It can be concluded that only treatments with $5 \%$ sulfurous acid resulted in complete alcoholic fermentation, i.e., dry wines and lowest absorbance in wines. Addition of reducing agents containing ascorbic acid and tannins increased total phenols, antioxidant activity and color intensity in wines. Significant differences in the aromatic profile of wines were noticed due to the difference in the total and individual aromatic compound concentrations. Based on the achieved results, a combination of potassium metabisulfite, ascorbic acid, gallotannins and ellagitannins positively influenced the concentrations and OAVs of some individual and total aldehydes, esters and terpenes with medial concentration of total $\mathrm{SO}_{2}$ in wine. 
Author Contributions: Conceptualization A.-M.J.K. and A.J.; methodology B.K.; software and writing-review and editing, D.P.; formal analysis, I.T.; investigation, J.B.; writing—original draft preparation, A.-M.J.K. All authors have read and agreed to the published version of the manuscript.

Funding: This research received no external funding.

Acknowledgments: The authors would like to thank IREKS AROMA d.o.o. for having kindly provided the enological agents used for the trials.

Conflicts of Interest: The authors declare no conflict of interest. The funders had no role in the design of the study; in the collection, analyses, or interpretation of data; in the writing of the manuscript, or in the decision to publish the results.

\section{References}

1. Chinnici, F.; Sonni, F.; Natali, N.; Riponi, C. Oxidative evolution of (+)-catechin in model white wine solutions containing sulfur dioxide, ascorbic acid or gallotannins. Food Res. Int. 2013, 51, 59-65. [CrossRef]

2. Boulton, R.B.; Singleton, V.L.; Bisson, L.F.; Kunkee, R.E. Principles and Practices of Winemaking; Chapman and Hall: New York, NY, USA, 1996.

3. Elias, R.J.; Waterhouse, A.L. Controlling the fenton reaction in wine. J. Agric. Food Chem. 2010, 58, $1699-1707$. [CrossRef] [PubMed]

4. Waterhouse, A.L.; Sacks, G.L.; Jeffery, D.W. Understanding Wine Chemistry; John Wiley \& Sons, Ltd.: Chichester, UK, 2016.

5. Danilewicz, J.C.; Wallbridge, P.J. Further studies on the mechanism of interaction of polyphenols, oxygen, and sulfte in wine. Am. J. Enol. Vitic. 2010, 61, 166-175.

6. Santos, M.C.; Nunes, C.; Saraiva, J.A.; Coimbra, M.A. Chemical and physical methodologies for the replacement/reduction of sulfur dioxide use during winemaking: Review of their potentialities and limitations. Eur. Food Res. Technol. 2012, 234, 1-12. [CrossRef]

7. Falguera, V.; Forns, M.; Ibarz, A. UV-vis irradiation: An alternative to reduce $\mathrm{SO}_{2}$ in white wines? LWT Food Sci. Technol. 2013, 51, 59-64. [CrossRef]

8. Guerrero, R.F.; Cantos-Villar, E. Demonstrating the efficiency of sulphur dioxide replacements in wine: A parameter review. Trends Food Sci. Technol. 2015, 42, 27-43. [CrossRef]

9. Vally, H.; Misso, N.L.A.; Madan, V. Clinical effects of sulphite additives. Clin. Exp. Allergy 2009, 39, 1643-1651. [CrossRef]

10. Ribereau-Gayon, P.; Dubourdieu, D.; Doneche, B.; Lonvaud, A. Handbook of Enology: The Microbiology of Wine and Vinifications: Second Edition; John Wiley \& Sons, Ltd.: Chichester, UK, 2006; Volume 1, ISBN 9780470010365.

11. International Organization of Vine and Wine, OIV. Available online: http://188.165.107.123/public/medias/ 2601/oiv-ma-c1-01.pdf (accessed on 22 May 2020).

12. Lisanti, M.T.; Blaiotta, G.; Nioi, C.; Moio, L. Alternative Methods to $\mathrm{SO}_{2}$ for Microbiological Stabilization of Wine. Compr. Rev. Food Sci. Food Saf. 2019, 18, 455-479. [CrossRef]

13. Morata, A.; Loira, I.; Vejarano, R.; González, C.; Callejo, M.J.; Suárez-Lepe, J.A. Emerging preservation technologies in grapes for winemaking. Trends Food Sci. Technol. 2017, 67, 36-43. [CrossRef]

14. Yıldırım, H.K.; Darici, B. Alternative methods of sulfur dioxide used in wine production. J. Microbiol. Biotechnol. Food Sci. 2020, 9, 675-687. [CrossRef]

15. Sonni, F.; Bastante, M.J.C.; Chinnici, F.; Natali, N.; Riponi, C. Replacement of sulfur dioxide by lysozyme and oenological tannins during fermentation: Influence on volatile composition of white wines. J. Sci. Food Agric. 2009, 89, 688-696. [CrossRef]

16. Barril, C.; Clark, A.C.; Scollary, G.R. Chemistry of ascorbic acid and sulfur dioxide as an antioxidant system relevant to white wine. Anal. Chim. Acta 2012, 732, 186-193. [CrossRef] [PubMed]

17. Panero, L.; Motta, S.; Petrozziello, M.; Guaita, M.; Bosso, A. Effect of $\mathrm{SO}_{2}$, reduced glutathione and ellagitannins on the shelf life of bottled white wines. Eur. Food Res. Technol. 2015, 240, 345-356. [CrossRef]

18. Bradshaw, M.P.; Barril, C.; Clark, A.C.; Prenzler, P.D.; Scollary, G.R. Ascorbic acid: A review of its chemistry and reactivity in relation to a wine environment. Crit. Rev. Food Sci. Nutr. 2011, 51, 479-498. [CrossRef]

19. Versari, A.; Du Toit, W.; Parpinello, G.P. Oenological tannins: A review. Aust. J. Grape Wine Res. 2013, 19, 1-10. [CrossRef] 
20. Pascual, O.; Vignault, A.; Gombau, J.; Navarro, M.; Gómez-Alonso, S.; García-Romero, E.; Canals, J.M.; Hermosín-Gutíerrez, I.; Teissedre, P.L.; Zamora, F. Oxygen consumption rates by different oenological tannins in a model wine solution. Food Chem. 2017, 234, 26-32. [CrossRef]

21. Morrot, G.; Brochet, F.; Dubourdieu, D. The color of odors. Brain Lang. 2001, 79, 309-320. [CrossRef]

22. Olejar, K.J.; Fedrizzi, B.; Kilmartin, P.A. Influence of harvesting technique and maceration process on aroma and phenolic attributes of Sauvignon blanc wine. Food Chem. 2015, 183, 181-189. [CrossRef]

23. Ferrer-Gallego, R.; Puxeu, M.; Nart, E.; Martín, L.; Andorrà, I. Evaluation of Tempranillo and Albariño SO2-free wines produced by different chemical alternatives and winemaking procedures. Food Res. Int. 2017, 102, 647-657. [CrossRef]

24. Gabriele, M.; Gerardi, C.; Lucejko, J.J.; Longo, V.; Pucci, L.; Domenici, V. Effects of low sulfur dioxide concentrations on bioactive compounds and antioxidant properties of Aglianico red wine. Food Chem. 2018, 245, 1105-1112. [CrossRef]

25. OIV. International Code of Oenological Practices. Part II Practice and Oenological Treatments; OIV: Paris, France, 2016.

26. Dukes, B.C.; Butzke, C.E. Rapid determination of primary amino acids in grape juice using an o-phthaldialdehyde/N-acetyl-L-cysteine spectrophotometric assay. Am. J. Enol. Vitic. 1998, 49, 125-134.

27. Singleton, V.L.; Rossi, J.A. Colorimetry of total phenolics with phosphomolybdic-phosphotungstic acid reagents. Am. J. Enol. Vitic. 1965, 16, 144-158.

28. Re, R.; Pellegrini, N.; Proteggente, A.; Pannala, A.; Yang, M.; Rice-Evans, C. Antioxidant activity applying an improved ABTS radical cation decolorization assay. Free Radic. Biol. Med. 1999, 26, 1231-1237. [CrossRef]

29. Glories, Y. La couleur des vins rouges II, Connaissance de la vigne et du vin. Vigne Vin 1984, 18, $253-271$.

30. Maslov, L.; Tomaz, I.; Mihaljević Žulj, M.; Jeromel, A. Aroma characterization of predicate wines from Croatia. Eur. Food Res. Technol. 2017, 243, 263-274. [CrossRef]

31. Falqué, E.; Fernández, E.; Dubourdieu, D. Differentiation of white wines by their aromatic index. Talanta 2001, 54, 271-281. [CrossRef]

32. Allen, M.S.; Lacey, M.J.; Boyd, S. Determination of Methoxypyrazines in Red Wines by Stable Isotope Dilution Gas Chromatography-Mass Spectrometry. J. Agric. Food Chem. 1994, 42, 1734-1738. [CrossRef]

33. Ohloff, G. The Fashion of Odors and Their Chemical Perspectives: Scent and Fragrances; Springer: Berlin/Heidelberg, Germany, 1994.

34. Jackson, R. Wine Science, 4th ed.; Academic Press: San Diego, CA, USA, 2014.

35. Ribéreau-Gayon, P.; Glories, Y.; Maujean, A.; Dubourdieu, D. Handbook of Enology, The Chemistry of Wine: Stabilization and Treatments, 2nd ed.; John Wiley \& Sons, Ltd.: Chichester, UK, 2006; Volume 2, ISBN 9780470010396.

36. Regulations of the Wine Production (2/2005). Available online: https://narodne-novine.nn.hr/clanci/sluzbeni/ 2005_01_2_17.html (accessed on 20 December 2019).

37. Vinković Vrček, I.; Bojić, M.; Žuntar, I.; Mendaš, G.; Medić-Šarić, M. Phenol content, antioxidant activity and metal composition of Croatian wines deriving from organically and conventionally grown grapes. Food Chem. 2011, 124, 354-361. [CrossRef]

38. Jakobović, S.; Jeromel, A.; Maslov, L.; Jakobović, M. Influence of grape ripeness of Rhine Riesling on the composition of polyphenolic compounds in must and wine. J. Food Agric. Environ. 2015, 13, $29-35$.

39. Jagatić Korenika, A.M. Utjecaj Hladne Maceracije na Polifenolni Sastav i Senzorna Svojstva Vina Kultivara Pošip, Maraština, Malvazija, Kraljevina i Škrlet (Vitis vinifera L.); University of Zagreb Faculty of Agriculture: Croatia, Zagreb, 2015.

40. Ivanova, V.; Vojnoski, B.; Stefova, M. Effect of winemaking treatment and wine aging on phenolic content in Vranec wines. J. Food Sci. Technol. 2012, 49, 161-172. [CrossRef]

41. Fairchild, M.D. The colors of wine. Int. J. Wine Res. 2018, 10, 13-31. [CrossRef]

42. Rapp, A.; Versini, G. Influence of nitrogen compounds in grapes on aroma compounds of wines. In Developments in Food Science; Elsevier: Amsterdam, The Netherlands, 1995; Volume 37, pp. 1659-1694.

43. Jackson, R.S. Wine Science Principles and Applications, 3rd ed.; Academic Press Elsevier: Burlington, MA, USA, 2008.

44. Toci, A.T.; Tamborra, P.; Crupi, P.; Cantarini, L.; Antonacci, D. Comparison of winemaking techniques to produce wines with low sulphur dioxide. In Proceedings of the 35th World Congress of Vine and Wine, Izmir, Turkey, 18-22 June 2012. 
45. Patel, S.; Shibamoto, T. Flavor compounds in wines produced from chardonnay grapes fermented with fruit juices. Food Sci. Technol. Res. 2003, 9, 84-86. [CrossRef]

46. Jackson, R.S. Wine Tasting, 2nd ed.; Academic Press Elsevier: Burlington, MA, USA, 2009.

47. Pino, J.A.; Mesa, J. Contribution of volatile compounds to mango (Mangifera indica L.) aroma. Flavour Fragr. J. 2006, 21, 207-213. [CrossRef]

48. Ferreira, V.; Ortín, N.; Escudero, A.; López, R.; Cacho, J. Chemical characterization of the aroma of Grenache rosé wines: Aroma extract dilution analysis, quantitative determination, and sensory reconstitution studies. J. Agric. Food Chem. 2002, 50, 4048-4054. [CrossRef] [PubMed]

49. Herrero, P.; Sáenz-Navajas, P.; Culleré, L.; Ferreira, V.; Chatin, A.; Chaperon, V.; Litoux-Desrues, F.; Escudero, A. Chemosensory characterization of Chardonnay and Pinot Noir base wines of Champagne. Two very different varieties for a common product. Food Chem. 2016, 207, 239-250. [CrossRef] [PubMed]

50. Ferreira, V.; López, R.; Cacho, J.F. Quantitative determination of the odorants of young red wines from different grape varieties. J. Sci. Food Agric. 2000, 80, 1659-1667. [CrossRef]

51. Amoore, J.E.; Hautala, E. Odor as an ald to chemical safety: Odor thresholds compared with threshold limit values and volatilities for 214 industrial chemicals in air and water dilution. J. Appl. Toxicol. 1983, 3, 272-290. [CrossRef]

52. Howard, K.L.; Mike, J.H.; Riesen, R. Validation of a solid-phase microextraction method for headspace analysis of wine aroma components. Am. J. Enol. Vitic. 2005, 56, 37-45.

53. Guth, H. Quantitation and Sensory Studies of Character Impact Odorants of Different White Wine Varieties. J. Agric. Food Chem. 1997, 45, 3027-3032. [CrossRef]

54. Yang, C.; Luo, L.; Zhang, H.; Yang, X.; Lv, Y.; Song, H. Common aroma-active components of propolis from 23 regions of China. J. Sci. Food Agric. 2010, 90, 1268-1282. [CrossRef]

55. Buttery, R.G.; Teranishi, R.; Ling, L.C.; Turnbaugh, J.G. Quantitative and Sensory Studies on Tomato Paste Volatiles. J. Agric. Food Chem. 1990, 38, 336-340. [CrossRef]

(C) 2020 by the authors. Licensee MDPI, Basel, Switzerland. This article is an open access article distributed under the terms and conditions of the Creative Commons Attribution (CC BY) license (http://creativecommons.org/licenses/by/4.0/). 